\title{
SOME LABOUR TROUBLES OF THE I790's IN NORTH EAST ENGLAND
}

The period of the great French Wars of 1793-1815 saw a crop of strikes and other disturbances in North East England. The end of the wars in 1815 was followed rapidly by the great seamen's strike of 1815 , which turned fundamentally on a question of redundancy. The object of this paper is to consider a series of disputes just before the outbreak of war, and during the war's early years, disputes which turned fundamentally on the equally perennial question of the regulation of wages at a time of rising prices. ${ }^{1}$

Long before the 1790's certain groups of workers in North East England had shown the ability to organise themselves with sufficient skill to bring effective pressure to bear on their employers and even on the local authorities. From the first half of the 18th century this had been true of the pitmen of the local coalfield, and the sailors of the Tyne and the Wear proved equally precocious. An embittered shipowner wrote in 1792 that for thirty years the seamen had been able to exert effective pressure in defence of their common interests - though he didn't put it in such mild terms. ${ }^{2}$ Effective organisation among the North East seamen was facilitated by the nature of the most important trade of those ports; the coasting voyages of the coal trade multiplied opportunities for contacts and cohesion more than an emphasis on deep-sea voyages could have done. Throughout the 1790's the merchant seamen of the area had cause to combine in their own defence. The Nootka Sound incident brought Anglo-Spanish friction in the early summer of 1790 , and foreign perils brought to the North East ports the usual accompaniment of the Impress Service of the Royal Navy. If the

1 The principal sources used for this paper have been the Home Office and Admiralty Papers in the Public Record Office (hereinafter cited as HO and Adm. respectively), local newspapers and documents in the Newcastle City Archives. The 1815 strike has been discussed in "The Seamen's Strike of 1815 in North East England", in: Economic History Review, Second Series, Vol. XXI, No 1, 1968. 2 HO 42/22. Thomas Powditch/Pitt, 3 Nov. 1792. This long letter, though written with obvious prejudice, gives a good deal of information about the seamen's strike of October-November 1792, and associated events. 
impressment on this occasion was much milder in its impact than that involved in the outbreak of a major war with revolutionary France in 1793 , it was sufficient to bring about excitement and signs of cohesion among the local seamen. ${ }^{1}$

The late summer of 1792 saw the capacity of the North East seamen mobilised for another purpose; rising prices faced them - as it faced many other working class groups - with the prospect of a distinct fall in their standard of living unless they could obtain some advance in their wages. Their situation was summed up by a sympathetic naval observer in the following terms: ${ }^{2}$

"The Wages of the seamen of this Port have not been encreased for a Considerable time back since which the price of every article of living has encreased very much."

The merchant seamen were naturally determined to fight against a situation which threatened a diminution in what they regarded as the proper standard of living for men of their station in life, and their determination brought them out on strike with the approach of the winter of 1792-3; wages for the Tyne seamen had long stood at the figure of $£ 2.10 .0$. for each London voyage, and with the onset of winter conditions they were faced with the prospect of these wages being applied to the longer voyages very frequent in the winter season. In October the seamen acted; their leaders brought before the shipowners a demand for an increase of wages during the six winter months, November to April, to $£ 3$ per voyage. At the same time, the seamen acted in a way which was already a traditional manner of giving point to their demands, and was to remain so into the second half of the 19 th century. They brought the coastal trade of the Tyne to a stop by enforcing the removal of the crews from all vessels in the harbour, and inducing or obliging the crews of vessels arriving in the Tyne to come out also.

The reaction of the shipowners was a refusal, of a kind which has played a notable part in the fomenting of industrial strife. It was a commonplace of such disputes that many employers consistently under-estimated the intelligence and ability of the men's leaders, and this miscalculation clearly appears in the resolutions passed at a

1 Adm. 1/2395 contains the letters to the Admiralty for this period of impressment from the Regulating Officer in North East England, Captain Peter Rothe.

2 HO 42/22. Cochrane/Dundas, 20 Nov. 1792. This long letter is another of the most useful documents relating to the seamen's strike, and is notably more objective than the Powditch letter cited above. 
meeting of shipowners called on 24 October to consider the men's demands for an increase in wages: ${ }^{1}$

"it is fair and reasonable that the Sailors should receive a proper Satisfaction for the Toil and Dangers of the Service they perform, but extravagant Wages only produce Mischief to the Sailors themselves, by drawing to the Port a greater Number of Men than can find Employment, and by inducing more Persons to follow the Sea than the Trade of the Kingdom can receive; besides, such Wages cannot, in the Nature of Things, last long."

The employers declared they would have been glad to consider an increase in winter wages "had not the Sailors of this Port taken illegal Measures"; now they durst not give way to such riotous measures, lest the shipowners themselves incur "the Penalty of the Law, as Encouragers of Tumult and Disorder..." The owners appointed a committee of 21 to represent their case to the authorities, and take such other measures as might be expedient, and the general meeting expressed a willingness, once the men returned to their proper obedience, to increase wages to $£ 3$ for the four months November to February.

The seamen were not taken in by this invitation to disarm themselves, and instead reacted promptly and effectively; they announced that no coal ship would be allowed to sail before agreeing to pay its seamen four guineas for the voyage to London and back. Ships submitting to these terms were identified in the harbour by their wearing a jack at the mast head. The interdict on the sailing of other vessels was maintained by large bodies of seamen, divided into regular watches, and maintaining a twenty-four hour guard at both sides of the harbour. ${ }^{2} \mathrm{~A}$ favourable wind for sailing and a buoyant demand in the London market induced some owners to submit to the men's inflated terms, and their ships duly sailed, speeded on their way by the cheers of the sailors on both banks of the river.

Many of the shipowners, however, were adamant in their refusal to yield to this pressure. This spirit of resistance, as their letters make clear, was not due simply or primarily to unwillingness to pay their men an extra ten shillings for the winter voyages, but to a deep-rooted determination to insist on the position of master, and a blank refusal to accept coercion at the hands of their employees. There was no consistently united front on the part of the employers, but a hard core of men in the Tyne shipping interest, mostly men in a fairly small way of

1 Newcastle Chronicle, 27 Oct. 1792.

2 Powditch/Pitt, 3 Nov. 1792. Loc. cit. 
business, men like Nicholas Fairles, Joseph Bulmer and Thomas Powditch, firmly believed that to yield to the demands of the seamen was not simply to lose an industrial dispute, but to contribute to the over-turning of that due subordination which was an essential ingredient in the established order of society. The party of resistance, however, had well founded doubts as to the extent of support in their obstinate stand which they might expect to receive from the local authorities of the area. ${ }^{1}$ In some instances, indeed, there was not any strong local authority at hand; South Shields was the most notable example of this, for in this growing town there was no resident magistrate, and while the central government and local interests prodded the Bishop of Durham to remedy this defect, it was not easy to find men of the station proper to a county magistrate in the area. ${ }^{2}$ On the other side of the river the magistrates of Northumberland displayed no keenness to interfere against the seamen. Although on the river itself there was no dearth of authority, since the control of the Newcastle magistrates over the whole harbour was acknowledged, past experience showed the more obstinate employers that in such a dispute the local authorities were reluctant to act forcibly if there seemed any equitable basis for the men's demands. Certainly the shipowners knew that they couldn't rely on the local magistrates making common cause with them in resistance. In the event it was clear that the great majority of local magistrates much preferred negotiation to confrontation, and as was to happen again in 1815 , the Newcastle magistrates allowed the seamen to paralyse the Tyne harbour for a number of weeks. While it is true that this attitude was not entirely due to indulgence, since the embattled seamen were not a body lightly to be tackled, and it took time to build up overwhelming forces, there can be no doubt that the local authorities hoped very much that the strike might be settled peacefully.

At the same time the magistrates could not simply look on supinely

1 Ibid. A number of other letters from the more recalcitrant shipowners echo this bitter resentment at the failure of the local magistrates to use force to break the seamen's strike.

2 Some little time earlier, Wallace, the Vicar of South Shields, had been made a Durham county magistrate to fill this gap in authority, but as he was not a very regular resident this didn't help much. After vainly trying to find someone else from the normal categories appropriate for such an office, the authorities concerned, mainly the Home Otfice and the Bishop of Durham, had to fall back on the appointment to the magistracy of Nicholas Fairles, who possessed neither the social status nor the financial security appropriate to such an appointment in normal circumstances. He proved an energetic, but not always a sagacious, magistrate. On Whit Monday, 1832, when in his seventies, he was brutally beaten to death by two pitmen. 
as control of the harbour was seized by unofficial bodies who forcibly prevented ships from sailing. As was normal in disputes affecting the harbour of Tyne, the Mayor and Aldermen of Newcastle took the lead in following a two-fold policy; in concert with magistrates of the affected areas of Northumberland and Durham they organised with the central government a rapid build-up of naval and military force, so that authority would be overwhelmingly superior in strength for any eventuality, while at the same time no encouragement was given to recalcitrant employers and every effort was made to forward conciliatory moves. Two circumstances enabled them to avoid intervention by force on the side of the shipowners. Most of the employers, not unreasonably afraid of future reprisals, were chary of coming forward to accuse individual leaders of the strikers, while the strikers took good care that when they were dealing with employers of known determined hostility, the men employed to enforce the blockade were strangers to the owners involved. ${ }^{1}$ On the other hand the leaders of the seamen were in full control of their followers, and there was very little violence; the only assaults recorded are the mild measures taken by the strikers to enforce discipline in their own ranks. On a few occasions men were carried through one of the local towns on a pole as a sign of ignominy, and a shocked employer added to a jeremiad sent to the Prime Minister on 3 November a post script relating that the strikers were driving a few sailors who had disobeyed their orders through the streets of North Shields naked. ${ }^{2}$ Yet the seamen skilfully avoided any major provocations which would have forced the local authorities to act against them.

At the beginning of November there were no signs of the seamen's grip on the harbour weakening, although naval and military re-inforcements were accumulating in the area. The naval and military officers on the spot were not automata, but had ideas of their own, which were very like those entertained by the local magistracy, and successive senior officers of the two services showed no inclination to accept the role of passive supporters of obstinate employers. When HMS Racehorse arrived in the Tyne towards the end of October her captain, Leckey,

1 HO 42/22. Joseph Bulmer/Evan Nepean, 9 Nov. 1792. Though addressed to the Secretary to the Admiralty this letter must have been forwarded thence to the Home Office. Another good example of the employers' reluctance to expose themselves to future reprisals occurs during the Wear keelmen's strike a few months later, in a letter of 19 Feb. 1793 from Thomas Sanderson (HO 42/24.) - " ... a smart Impress among the Keelmen ( 300 of whom can well be spared) will restore us to peace, but I would not for the world that this hint should fall from our lips, so as to find its way by any means to the North ..."

2 Powditch/Pitt, op cit. 
at once joined the ranks of those interested in finding a peaceful settlement of the dispute, and his attempts at mediation earned him the hostility of some of the hard core shipowners. ${ }^{1}$

Leckey's advocacy of conciliation at a meeting of shipowners on 31 October succeeded in arranging a conference between the two sides, which was held on board HMS Racehorse, with Leckey and Clayton, the Town Clerk of Newcastle, in attendance. The owners' decision to attend this conference had been reached against the strenuous opposition of an obstinate minority, whose spokesman was Thomas Powditch. This man, who described himself truthfully as "a person of more spirit than prudence", 2 thought Leckey's intervention "very improper", and opposed the whole idea of a conference. In his speech at the meeting on 31st October Powditch declared that:

"it is my opinion that Tampering with a Mob, treating with Rioters, or offering terms to People illegally assembled for the purpose of extorting high wages from their employers are crimes little inferior in magnitude to rioting itself."

Powditch was, however, willing to admit that Leckey's motives had been good, though the failure of the meeting on board HMS Racehorse simply proved, for Powditch, the folly of negotiation before forcing a surrender. Leckey's well-meant intervention provoked a series of letters of complaint to the central government by the more obstinate shipowners, who expressed in strong terms their sense of the way in which the local authorities were failing in their duty. In particular the Newcastle authorities were denounced for confining their attention to the collection of dues from the harbour, while they would do nothing to protect the property which provided their town with this revenue. ${ }^{3}$

The attitude of the distant central government was not a simple and obvious one. In the early days of the dispute Lord Grenville, as his reputation might suggest, was hostile to the strikers, and called for the suppression of the strike: $\mathbf{4}^{\mathbf{4}}$

1 Ibid., and letter from Captain Leckey to the Mayor of Newcastle 3 Nov. 1792, in which Leckey ruefully refers to this reaction (Newcastle City Archives).

2 Powditch/Pitt, op cit.

3 These complaints were by no means without foundation. Newcastle took much more in revenue from the Tyne harbour than was ever expended on harbour works. The struggle against Newcastle's monopoly control was a major local political issue till the turn of the 19th century. Some discussion of the later stages of this struggle occurs in N. McCord and A. E. Carrick, "Northumberland in the General Election of 1852", in: Northern History, Vol. I, 1966.

1 HO 43/4. Grenville/Bishop of Durham, 7 Nov. 1792. 
"I trust there can be no doubt, but that by a proper Exertion on the part of the Magistracy any further Mischiefs may be prevented, $\&$ a stop put to the Spirit of Combination which appears to have prevailed."

It is noticeable, however, that as more definite information on the situation became available, especially from the naval and military men on the spot, the central government, while hastening the build-up of the forces of authority, refrained from issuing those definitive orders which would have obliged the local authorities to use these forces to crush the seamen.

On 7 November the brig Mary attempted to sail; her crew had signed ship's articles in the normal way, although the strikers had forbidden such a practice - perhaps because this might be used as evidence that the men concerned had joined in the extortion of the higher wages enforced on ships allowed to sail. A band of seamen boarded her, and tore out the pages involved from the ship's articles. They returned a little later and removed the whole book before the brig was allowed to leave the port. ${ }^{1}$ This event brought a renewed flurry of activity by the local authorities, in response to complaints from the shipping interest. A meeting of the magistrates of the three counties (Newcastle, Northumberland and Durham) was held at Newcastle on 8 November, but resulted in no change in policy. They rejected any plans for the immediate use of force but instead deputed one of their number, Rowland Burdon, to make another attempt at mediation. This decision was taken with the full concurrence - and perhaps the encouragement - of the senior naval and military officers present. A further series of complaints went off to the central government from aggrieved shipowners. ${ }^{2}$ Rowland Burdon was a Tory MP for Durham, a county magistrate, a well-known figure in coal and shipping circles, and a man with a genuine local popularity among all classes. Before seeing the seamen's leaders he succeeded in obtaining from the employers a concession of an offer of $£ 3$ per voyage for the months of October to March. The seamen refused this offer, though they welcomed the intervention of the magistrates as mediators. Not all things were going well for the strikers. They were not blind to the strength of the armed forces being accumulated by the authorities, and on 11 November they learned that the Admiralty had declined to take any action on a petition they had

1 HO 42/22. Affidavit of Nehemiah Blagdon, Master of the brig Mary, 22 Nov. 1792.

2 The best example is HO 42/22, Joseph Bulmer/Nepean, 9 Nov. 1792, claiming that the shipowners were "quite neglected" by the Newcastle authorities. 
submitted there in support of their case - a step the seamen were to repeat in subsequent disputes; on this occasion the Admiralty wrote to Leckey to tell him that the petition would not be acted upon, as it was unsigned and undated ${ }^{1}$ - "... My Lords do not think themselves competent to interfere therein..."

However, the Royal Navy's part was not to be a negative one. On the evening of 15 November, just after the failure of Burdon's first negotiation was clear, the naval forces in the Tyne were re-inforced by the arrival of the frigate HMS Hind. Captain the Hon. Alexander Cochrane, her commander, took over the role of senior naval officer. He was to show himself a man of humanitarian views and a cool and sensible observer. He had already during his present commission demonstrated that he shared the generous sympathies of his more famous nephew, Thomas Cochrane, the 10th Earl of Dundonald. He had been appointed in Hind to the Leith station primarily for antismuggling duties, but he had signalled his arrival in January 1791 by ending a series of disgraceful abuses in the treatment of sick seamen on that station, with the Admiralty's full approval. More recently, in the summer of 1792, he had received the thanks of both the civic authorities and the Admiralty for the part he had played in composing local troubles in Edinburgh.

It should not be supposed that naval and military officers delighted in coming to the aid of the civil power; for the most part such missions came as an unwelcome distraction from proper tasks, and were not infrequently, in the view of the army and navy, the result of ineptitude or neglect of duty on the part of the civil authorities. Cochrane was no different from other officers in this position; Hind, after a strenuous commission, was badly in need of a re-fit, and to add to his concern on this score she grounded on the bar when entering the Tyne on $\mathbf{1 5}$ November. Cochrane was under orders from the Admiralty to proceed to Sheerness as soon as possible, and was anxious to get his ship into dockyard hands as quickly as his police duty in the Tyne could be terminated. As Leckey seems to have done before him, he soon came to have a very poor opinion of many of the employers ${ }^{2}-$

"the Owners whom I am sorry to say that the sailors have but too much reason to complain of"

Cochrane found ample evidence that the seamen had often been cheated

1 Adm. 2/767. Admiralty/Leckey, 11 Nov. 1792.

2 Most of Cochrane's letters during these months which bear on the North East troubles are in Adm. 1/1617, but this quotation is taken from Cochrane/Dundas, 20 Nov. 1792, in $\mathrm{HO} 42 / 22$. 
by some of their employers in the past. Although the Admiralty had now equipped him with sufficient strength in the shape of a sizeable squadron and an additional force of Marines for him to break the seamen's grip on the harbour if he cared to do so, Cochrane made no attempt to use force. Instead he used his influence to support another attempt at mediation by Burdon, while at the same time he emphasised in reports to the Admiralty that the seamen were "perfectly quiet". 1 Other independent opinion was kindly disposed towards the strikers. The local newspapers, by no means always tolerant of strikers, were on the whole more moderate in their attitudes than they were to be in similar disputes in 1815 and subsequent years. The Whig Nerecastle Chronicle, for instance, though on 3 November it published a report that the strikers' reprisals against their own delinquents were "harsh and brutal", in its next number published a denial of this earlier report in the most downright terms and asserted instead that

"they conduct themselves with much greater propriety than could be expected from the nature of their agitated situation."

Early on 19 November another meeting was held at Newcastle; a group of magistrates including Burdon, and with Cochrane's powerful support, succeeded in wringing from a delegation of shipowners some concessions which enabled Burdon to tackle the men's leaders again with some hopes of success. There followed later in the day a prolonged conference at South Shields between Burdon and the strike leaders, the result of which was anxiously awaited by a large crowd of seamen gathered outside. Burdon made it clear that if these new terms were rejected the authorities would have no alternative but to end the paralysis of the port forcibly. Finally the terms were accepted; the higher wage rate for winter voyages was to extend to the end of May, there was a concession about food for the men on board ship, and Burdon agreed that he would take the first opportunity to bring before Parliament a Bill to set up a statutory wages board for seamen's wages, on which both owners and seamen would be represented, and which would have power to fix the wages to be paid in future. On hearing the news, the waiting crowd of seamen were very pleased, and before they separated they gave cheers for the shipowners. Burdon was not at first sure that it would be over as easily as that, but in fact with this agreement the strike over wages was peacefully concluded. In a report to the Home

1 Adm. 1/1617, Cochrane/Admiralty, 16 Nov. 1792. In his letter to Dundas of 20 Nov. 1792, already cited, Cochrane wrote of his impression on arriving in the Tyne of the seamen's "utmost degree of civility and regularity" except for the blockade itself. 
Office on 21 November, the senior army officer on the spot, Colonel Delancey, expressed his opinion that if the employers and magistrates had acted in a manly and proper way from the beginning of the dispute all the subsequent trouble and the diversion of armed forces could have been avoided; certainly it seems clear enough that the offer of terms like these in October would have stood a good chance of averting the strike altogether. ${ }^{1}$ On 23 November Burdon wrote to the Home Office to express the hope that it would be possible to countermand the march of additional troops ordered up from York as "the Durham people will be much disposed to grumble if they are so visited for their neighbours" offences..."

The story of this strike then is not one of brutal oppression. Perhaps rather the atmosphere is more accurately typified by an incident during the dispute reported by the Nerecastle Chronicle. ${ }^{2}$ When HMS Martin arrived in the Tyne to join the security forces she grounded heavily, and the efforts of her crew were unable to extricate her from this predicament. She was however rescued by the strikers, who sent groups of boats to pull her off the shoal; the Chronicle reports the meeting on board Martin between her captain, Duff, and one of the strikers' leaders who declared

"We know well enough, by God, Captain, what you've come about, but, damn it, we'll save His Majesty's ship for all that."

The seamen were not the only local group of workers with grievances about wages in late 1792 and early 1793, and there were a crop of other disputes in these months. The fruits for the strikers varied but a number of wage advances were won. One strike which, however, failed in its object was a strike of keelmen on the Wear in February 1793 ; in this instance, the authorities reacted promptly and strongly to a number of provocations. Not only did the strikers here punish their own delinquents, but they also took strong action against blacklegs and informers - one old man informed the magistrates of the names of some keelmen who had forcibly prevented a loaded keel from moving on the river, with the result that he was paraded through Sunderland on a pole, his house was broken into and his furniture destroyed. The keelmen went on to block the Wear completely by mooring a double line of keels from bank to bank. The strike was broken by the arrival of a force of Dragoons from Newcastle; a collision between troops and strikers led to shooting by the Dragoons,

1 HO 42/22. Delancey-Grenville, 21 Nov. 1792.

21 Dec. 1792. 
but happily there was no bloodshed. The keelmen returned to work without receiving the wage increase they had demanded, but if a local correspondent was right in reporting to the central government that they earned at least $£ 40$ a year, and some of them up to $£ 80$, then they were not perhaps suffering as much as some of their fellowworkers in these months. ${ }^{1}$

The North East collieries also had their share of trouble. In late February a group of Durham pits came out on strike, but after a prolonged conference between the pitmen's leaders and some county magistrates at Gateshead the men returned to work with only minor concessions. ${ }^{2}$ In Northumberland trouble began a little earlier, in late December 1792. A dispute at a pit at Walker led to a strike, and the agent of the colliery brought prosecutions against some ringleaders who had been involved in a fracas arising out of the dispute. The accused men were brought before two Northumberland county magistrates who, to the agent's great annoyance, paid little attention to his tale of woe, but instead tried hard to persuade the men to go back to work, and finally quashed the cases brought against them. Disputes in the local collieries dragged on well into February when the Mayor of Newcastle was able to report thankfully to the Home Office that ${ }^{3}$

"The exertions of the Gentlemen concerned in the Coal Trade accompanied with some Compliance on the Score of Wages have in a considerable Degree appeased the Colliers."

Successful demands for wage increases were also made by local carpenters, joiners, shoemakers and staymakers in the same months. ${ }^{4}$ In all these disputes there was no action on the part of the authorities to provoke bitterness, but a very strong desire for conciliation if this could be obtained on reasonable terms. Indeed if the story of this series of troubles could be ended here, we would be left with a bright enough picture of social relations in North East England during these years. There is yet, however, a darker chapter to recount, in which the blindness of the central government to a danger which was obvious

1 HO 42/24. T. Sanderson/R. Burdon, dated only Feb. 1793.

2 Newcastle Chronicle, 23 Febr. 1793.

3 HO 42/23. James Rudman (Mayor of Newcastle)/Dundas. A full account of the abortive prosecutions and their treatment at the hands of the county magistrates Bigge and Fenwick is in a letter from Thomas Barnes of 23 Feb. 1793, also in HO $42 / 23$.

4 These disputes are mentioned in both the Chronicle and the Courant, and appear as incidental points in many of the letters written by local correspondents during the 1793 strikes in the coal mines and on the Wear keels. 
enough to many others was to bring the country into very serious peril.

By the end of 1792 the seamen of the North East ports had passed through a prolonged period of excitement, and had just emerged victorious from a major strike for higher wages. It was in this circumstance that the deteriorating relations between Britain and revolutionary France brought upon the seamen the full force of the Royal Navy's Impress Service, operating on a scale of intensity much greater than that which had been involved in the "Spanish armament" of a few years before. This inaugurated a new crisis for the merchant seamen, which reached a peak in the early months of 1793 , but then smouldered on dangerously for several years. Naturally enough the seamen disliked the method of manning the Navy by impressment, but many of them shared the prevailing belief that impressment was a very unpleasant necessity; the factor which injected the real bitterness in these years was the miserably low figure of the wages paid in the Royal Navy. Naval wages were not only much lower than those in merchant service, in a period of rising prices they were not enough to provide a decent standard of living for the families of pressed men. The ordinary naval seamen's pay might well amount to little more than five shillings a week, nor was regular payment to be depended upon; not surprisingly, it was looked upon as a derisory reward for men who were expected both to risk their lives and exist in miserable conditions aboard Britain's wooden walls.

On 12 December 1792 Captain Peter Rothe was ordered by the Admiralty to re-open the Impress Service on Tyne and Wear. Rothe had served in this capacity in 1790 , and was personally popular with the local seamen. ${ }^{1}$ He played the hard game of impressment by its rules, and seized for the King's Service only those properly liable to impressment. (The Impress Service has not been kindly dealt with by tradition; an attentive study of the evidence will suggest that it wasn't as bad in practice as its posthumous reputation suggests. ${ }^{2}$ ) For example, during a "hot press" at North Shields on 16-17 March 1793 the Tyneside gangs seized 60 men; on 28th they were examined by Rothe, who released 22 of the captives on the grounds that they were mates, ships' carpenters, or apprentices, and therefore exempt from impressment. Even more striking were the results of the particularly strenuous press of 26-27 April. After North Shields had been sealed off by troops,

1 Rothe's letters on the 1793 impressment crisis are in Adm. 1/2396, the Admiralty's side of the correspondence in Adm. 2/768 and 769.

2 For a fuller account of the Impress Service in practice, see N. McCord, "The Impress Service in North East England during the Napoleonic War", in: The Mariner's Mirror, Vol. 54, No 2, 1968. 
press gangs entered the town and made a thorough search, which netted more than 250 captives; on 28 and 29 April Rothe examined them, and eventually detained only 40 for His Majesty's Service. ${ }^{1}$

Yet this restraint could not avoid the immense bitterness with which in these months the seamen contemplated the miserable pittance of naval wages. Their stand was a justified one, but all their efforts in these months were unavailing. Local interests badly affected by the difficulty of obtaining crews sought to solve the problem by inducing sufficient seamen to volunteer for the Navy by offering bounties; Newcastle Corporation, Newcastle Trinity House, and an unofficial fund collected for the purpose joined in, until by February 1793 an able seaman volunteering for the Royal Navy received at once a total of £9. 4. 0. (One of Rothe's Lieutenants, a man with local connections, earned a reprimand from the Admiralty for allowing pressed men to claim the status of volunteers after their capture, in order to secure them the bounty money. ${ }^{2}$ ) The attitude of the local affected interests was not simple altruism; while the press gangs were at work it was difficult to find any seamen at all, and owners were having to pay very high wages for unsatisfactory complements. It could be hoped that if the bounties would supply the Navy with the men it needed, the heat would be taken off the remaining seamen. The Admiralty was also not above a degree of blackmail; it was customary for certain groups of workers to be given official exemptions from impressment, but the Admiralty witheld these protections from the North East ports while the seamen continued to resist impressment. Only repeated protests in and out of Parliament by local representatives brought about a relaxation of this attitude. ${ }^{3}$

Despite the unyielding attitude of the Admiralty, the North East seamen tried hard to bring home to the central government the disgraceful business of naval seamen's wages. In part this was done by offering a resistance to the press gangs more strenuous than usual in these circumstances; members of the gangs were beaten up, captives were rescued, and threatening letters were received by members of the Impress Service. However, Rothe himself was treated with

1 For the March impressment Adm. 1/2396, Rothe/Admiralty 20 Mar. 1793. For the April incident Newcastle Chronicle, 4 May 1793.

2 Adm. 1/769, Admiralty/Lieut. William Abbs, in charge of impressment on the Wear. This benevolent fraud seems to have been commonly connived at.

3 One of Northumberland's MPs, Grey, was active in trying to induce the Admiralty to relent, and then on 9 th May 1793, supported by Lambton, he complained in the House of Commons of the activities of the Impress Service in the North East, receiving only the promise that enquiry would be made into his criticisms; Newcastle Chronicle, 27 Apr. 1793 and 18 May 1793. 
respect, which indeed he fully earned, for the seamen's case was made very clear at the Admiralty by a series of letters in which Rothe recounted the dialogue he carried on with the seamen's leaders. Like the local authorities, ${ }^{1}$ he forwarded to the central government the arguments he heard from the seamen; on 4 February 1793 he sent on to the Admiralty a printed handbill issued by the seamen, who had given him this copy -

"Bounties, however large they may appear at first, do not last long; and when they are expended in Cloaths and other Necessaries, we are obliged to live upon the same pay as before, which we well know from experience we cannot live upon ... Besides, does not this offer of additional Bounty plainly shew, that the Association and others are of opinion that our present Pay is not sufficient? Else why do they offer it? We have always shewn a Readiness to meet the Enemies of our Country, so that our present Objections do not proceed from Cowardice, but from the dreadful Miseries which we have known, seen, and felt, in our Families and Connections... Twenty-two Shillings a Month, Fellow-Seamen, is Five Shillings a week! A Sum too small for even a single Man to live upon; but many of us have Wives and Families, many Mothers, Sisters, and other Relations, whose very Existence depends upon our Lives and Success; From these we are torn and compelled to accept this small sum, which is not Half what we receive in the Merchants' Service... if we are such Friends to our Countrymen that we are always ready to step forward in their Defence, why should our situation in Time of War be rendered so much worse than in Time of Peace? We can then live comfortably, support our Families decently, give our Children an honest and useful Education, and make them good and worthy Members of Society. - In Time of War we cannot, from the miserably small Pay, even live ourselves. But this is not the worst. - Our Children and Dependents are neglected; they are exposed to all the Miseries of Poverty, and hindered in their Course of Life by Want of Protection and Education. These are great Calamities; and it is to remedy these, not to create Disturbances, that we desire you to consider seriously these Grievances; But tho' we hope they will be redressed, yet in order to attain so desirable an end, we will preserve Peace and

1 Another good example is provided by Rudman/Dundas, 31 Jan. 1793, transmitting to Home Office information about the seamen's activities, and in particular the cogent and sensible resolutions passed at a meeting of seamen on the previous day. HO $42 / 24$. 
Order; no Violence shall disgrace the Conduct of Men who are engaged in so good a Cause."

All of this information and argument fell on deaf ears at Westminster.

In February the leaders of the North East seamen decided to petition the House of Commons for higher naval wages. They had high hopes that their eminently reasonable plea would be heeded; on 9 February the Mayor of Newcastle told the Home Secretary that since the local seamen had decided on this plan they had become more calm. ${ }^{1}$ On 25 February their petition was introduced into the House of Commons. After a brief discussion, in which Pitt spoke against receiving the petition, the House declined to accept it on the technical grounds that it related to Money for Public Service, but was not recommended by the Crown. Nothing was done to improve naval wages, and instead the war crisis led the Government to use its strength to enforce impressment on a large scale. It would be wrong to say that Pitt's Government failed to pay attention to the problems of naval recruitment, but their efforts in the various Quota Acts to find alternative methods to impressment missed the main social problem, and were in any event rendered unsuccessful by the weaknesses of the country's administrative resources.

Burdon's scheme for the statutory regulation of seamen's wages also came to nothing; although an honest and well-meaning man, he was no great Parliamentary orator, and in face of a very cold reception from the shipping interest and from the Government, his plan fell to the ground. ${ }^{2}$ In 1796 the merchant seamen on the Tyne tried to repeat their success of 1792 by striking and forcibly preventing the sailing of ships in support of a claim for higher wages. This time, however, an unpleasant surprise was in store for them; the armed boats of the Navy's Impress Service descended on them, and 42 strikers were seized and carried off to the naval tender moored in the Tyne, though in the event Rothe only kept three of these men for the Royal Navy. ${ }^{3}$

In 1794, 1795 and 1796 the Impress Service continued at work, while the central government made no serious attempt to improve conditions of naval service. These years brought an increase in the number of attempts by desperate pressed men to escape from the naval tenders. Some of these were successful, and they involved some very tough fighting. The critical year 1797 saw three of these conflicts in the Tyne alone. It was clear throughout that the main poison in the situation in these years was not the existence of impressment, but the conditions

1 HO 42/23. Rudman/Dundas, 9 Feb. 1793.

2 A short biography of Burdon appears in Brockie's "Sunderland Notables".

3 Adm. 1/2399. Rothe/Admiralty, 24 May 1796. 
and wages which impressment led to in the Royal Navy. The Mayor of Newcastle told the Home Office clearly enough in February 1793 that ${ }^{1}$

"The Idea most dwelt on by the Sailors is an Augmentation of Wages and some easy Mode of remitting a part home to their Families."

The way in which the Government was taken by surprise by the outbreak of the naval mutinies of 1797 represents a serious dereliction. Even without the evidence emanating from the Navy itself, and from other quarters, the information which came in to Westminster from the North East alone should have alerted Ministers to the justified grievances of the seamen. The mutinies were not caused by impressment, and the activities of the Impress Service were not the main complaints made by the mutineers; wages and conditions provided the main spur, and the previous neglect of this grave situation led to the collapse of our naval defences at a critical time. It seems clear enough that this danger could have been easily averted by reasonable and timely concessions. Among the many achievements of Pitt's first ministry this must stand as one of the notable failures.

Indeed, if the central government in this business had shown itself as sensible as the local authorities in the North East during the crop of disputes in 1792-3, then the danger could have been avoided. However, as these earlier events demonstrated, the ineptitude shown in the handling of the question of naval wages was not necessarily typical of authority's role in these years. Many elements of authority were capable of acting in a moderate and considerate way towards workers' demands. Moreover, the other side of the coin is similar; the background of these various disputes does not present the picture of a working class alienated from the established order of society. In November 1792, at the height of the seamen's strike, Burdon told the Admiralty that ${ }^{2}$

"It is with Pleasure that I can add that there seems nothing of a Political Nature in the present matter, \& that the Sailors appear heartily attached to the Government of the Country."

1 HO 42/24. Rudman/Dundas, 4 Feb. 1793. For some other useful reflections on the Impress Service, and some strictures, perhaps not wholly unjustified, on some of its critics, see W. N. Glascock, "Naval Sketch Book", Vol. II, p. 75 et seq. In the early 1830's Glascock, then Commander RN, played a similar part to that of Cochrane in 1792, during strikes on Tyneside.

2 HO 42/22. Burdon/Nepean, 16 Nov. 1792. 
At the end of January 1793, under the immediate threat of impressment and miserable naval conditions, the seamen declared in the resolutions of one of their general meetings that they "admire and venerate" the constitution. ${ }^{1}$

There are it is true three scraps of evidence which might lead to a different conclusion, but they will not bear much weight. In one group of Home Office Papers" there is a note which says "Newcastle Nov. 22nd. Mr. Massey ... two thirds of the people ripe for revolt, the magistrates afraid to act." Anyone who has worked much with these sources will approach such a vague alarm sceptically, and it is perhaps significant that the old Home Office wrapper with this group is endorsed succinctly "Newcastle. Seditious Proceedings on acct. of Wages." Joseph Bulmer, of South Shields, who appears for decades as a purveyor of exaggerated and unsubstantiated terrors from Tyneside for the benefit of the Home Office, informed Burdon on 18 February 1793 that a pole inscribed "Liberty for ever" had appeared that day in South Shields market place, but claimed too that the workers didn't know what they really wanted, and were encouraged in sedition by people of higher rank. ${ }^{3}$ In November 1792 another local correspondent reported a rumour that in the previous summer 1000 copies of the sixpenny edition of Paine's works had been sold on Tyneside, but stated definitely that at the time of writing ${ }^{4}$

"No seditious handbills have been circulated here; nor have I heard of any pamphlets of such a tendency."

Much more eloquent than any of these scraps, however, is a notable piece of negative evidence. The local newspapers, both Whig and Tory, were alert to report any evidence of politically subversive activity anywhere. There is a total absence of any suggestion that the strikes, and the activities of the merchant seamen in agitating for naval reforms, had any possible connections with politically subversive activities. It is incredible that if any such connection existed, or was suspected seriously, no reference to it would occur in these sources, yet the blank is undeniable. At first sight it might seem that the 1797 mutinies prove a very different attitude on the part of the seamen, but full consideration suggests a different conclusion. Recruitment by impressment began

1 HO 42/24. Rudman/Dundas, 31 Jan. 1793.

2 HO 42/23.

3 Bulmer/Burdon, 18 Feb. 1793. For further discussion of Bulmer's unreliability as a witness in such matters see N. McCord, "Tyneside Discontents and Peterloo", in: Northern History, Vol. II, 1967.

${ }^{4}$ HO 42/23, Christopher Blackett/F. Freeling, 27 Nov. 1792. 
again at the end of 1792, without any improvements in naval conditions. For the next few years the seamen sought desperately to bring their plight to the attentions of Government by a variety of legitimate channels, without success, yet it was not until 1797 that they were driven to mutiny. Moreover, the aftermath of the mutinies is equally instructive. At Spithead, prompt concessions on the main grievances brought a peaceful return to obedience and no reprisals. At the Nore, the situation was complicated by the way in which Parker and some of the other leaders of the mutiny went far beyond the original grievances in their provocation to authority, but even there the reprisals by the authorities are surely notable for the restricted rather than the widespread form they took. The principal offenders were subjected to the full rigours of the law, but that was all.

Britain in the late eighteenth and early nineteenth centuries always contained magistrates and employers whose restricted vision could penetrate no further than a policy of unyielding and obstinate resistance to any manifestations of discontent on the part of the workers. There were also men who felt that the existing order in society and constitution was so irremediably bad that nothing would do but a complete break and a new start. Neither of these attitudes, however, was dominant or characteristic of the period. At all levels of British society enthusiasm for, or acquiescence in, the existing order of society, was a much more typical sentiment. When social troubles emerged, the characteristic response was not to abandon existing institutions, but to try to make them work to solve the problem. One of the most remarkable features of that society was the very large number of cases in which this approach did work.

In the 1790's the working classes of Britain were not an oppressed proletariat, helpless before an unholy alliance of employer and authority. The reality was at once more complex and more healthy. 